\title{
Antioxidant capacity of pitcher (Nepenthes) extract on oxidative rancidity of sun-dried squid
}

\author{
*Minh, N.P. \\ Faculty of Biotechnology, Binh Duong University, Vietnam
}

\begin{abstract}
Article history:
Received: 6 June 2021

Received in revised form: 23 July 2021

Accepted: 18 September 2021 Available Online: 3 October 2021
\end{abstract}

\section{Keywords:}

Pitcher extract,

Dried squid,

Acid value,

Carbonyl value,

Peroxide value,

Oxidative rancidity

DOI:

https://doi.org/10.26656/fr.2017.5(5).404

\begin{abstract}
Consumers demand new biologically natural-active ingredients with a great capacity to promote a healthier advantage and free from toxicity. Pitcher (Nepenthes) is one of the naturally carnivorous climber herbs. Extract from Nepenthes plant contains numerous beneficial bioactivity characteristics. This research compared the impact of $0.05 \%$ pitcher extract demonstrated with $10 \mathrm{ppm}$ butylated hydroxyanisole on the accumulation of acid value, peroxide value, carbonyl value and thiobarbituric acid during 12 months of storage. Results showed that there was no significant difference between $0.05 \%$ pitcher extract and $10 \mathrm{ppm}$ butylated hydroxyanisole in respect of acid value, peroxide value, carbonyl value and thiobarbituric acid during preservation of the dried squid. Pitcher extract would be a promising alternative to replace synthetic antioxidants to overcome oxidative rancidity in the dried seafood.
\end{abstract}

\section{Introduction}

Pitcher (Nepenthes) is an important tropical carnivorous pitcher plant widely distributed in Vietnam and Southeast Asian countries. Pitcher (Nepenthes) has a unique pitcher organ growing from the tip of the leaf (Wang et al., 2009). It is able to trap and digest insects to obtain nutrients (Wan-Nor-Adibah-Wan et al., 2016). Nepenthes are commonly utilized as a folk remedy to cure different ailments. It has been reported to be effective to cure gastrointestinal discomfort, regulate the menstrual cycle, ease child-birth, relieve asthma, treat eye inflammation, gastric ulcer, jaundice, high blood pressure and astringent (Aung et al., 2002; Schwallier et al., 2015; Van Thanh et al., 2015; Thao et al., 2016; Sanusi et al., 2017). Its extract contains numerous phytochemical constituents like steroids, flavonoids, alkaloids, terpenoids, tannins (Shuaibu et al., 2017). Extract from this plant is responsible for pharmacological properties like cytotoxicity, antiinflammatory, antibacterial, antidiabetic, antifungal, antioxidant, antimalarial, antiosteoporotic and hypolipidemic potentials (Likhitwitayawuid et al., 1998; Shil et al., 2010; Ismail et al., 2015; Van et al., 2015).

Lipid oxidation induces decomposition and degradation in three steps: initiation, propagation, and termination (Frankel, 1984; Fraser and Sumar, 1998). Rancidity in seafood could be initiated and propagated by peroxidase, lipoxygenase, auto-oxidation, photosensitized oxidation (Hsieh and Kinsella, 1989). Squid is one of the most important seafood species. There is increased consumer demand for dried squid in the world. It is rich in unsaturated fatty acids therefore it is susceptible to oxidative rancidity (Losada et al., 2007). Lipid oxidation results in protein denaturation leading to lower quality of the dried product (Lugasi et al., 2007; Beck, 2014). Artificial antioxidants such as butylated hydroxyanisole, butylated hydroxytoluene, tertiary butylated hydroxyl quinone and propyl gallate are commonly used in the seafood industry to control lipid oxidation. However, there are different health concerns when using these substances (Patel et al., 2010; Carocho and Ferreira, 2013; Reddy and Grace, 2016). Natural extracts with bioactive functions are highly preferred to replace synthetic antioxidants (Barros et al., 2007; Thao et al., 2016). Phenol-rich plant extracts such as the summer savoury flavoured powder, beetroot leaf extract and olive polyphenol successfully inhibited lipid and protein oxidation (Stina et al., 2020). Natural antioxidants from fruits, vegetables, herbs, and spices included beneficial essential oils suitable for seafood preservation by preventing oxidative chain reactions and prolonging the stability of these products (Lorenzo et al., 2018; Smaou et al., 2019; Sood et al., 2020; Alirezalu et al., 2020; Munekata et al., 2020; Dominguez et al., 2020; Mirian et al., 2021). Plant extract had antifungal, 
antioxidant, antimutagenic activities, and retard lipid oxidation in seafood (Cando et al., 2014; Ghayempour et al., 2015; Ashrafi et al., 2018; Kharchoufi et al., 2018). There was not any research that mentioned the utilization of pitcher extract to control lipid oxidation in the dried squid during storage. Therefore, the purpose of our study focused on the influence of pitcher extract demonstrated with butylated hydroxyanisole on the accumulation of acid value, peroxide value, carbonyl value and thiobarbituric acid during 12 months of storage.

\section{Materials and methods}

\subsection{Materials}

Raw squids were obtained from Tran De district, Soc Trang province, Vietnam. Nepenthes was collected from Da Lat district, Lam Dong province, Vietnam. A $100 \mathrm{~g}$ of Nepenthes was extracted under an alcoholic-aqueous solution $(70 \% \mathrm{v} / \mathrm{v})$ at $45^{\circ} \mathrm{C}$ for $3 \mathrm{hrs}$. The Nepenthes extract was obtained via filtration (Whatman paper No. 1). Chemical reagents were all analytical grade purchased from Fluka (Switzerland) and Sigma Aldrich (USA).

\subsection{Methods}

Squids were preliminarily gutted and washed under tap water to remove the ink. They were soaked in Nepenthes extract, butylated hydroxyanisole (BHA) solution (10 ppm) and control (without any additive) for 90 mins. They were dried under sunlight for 3 consecutive days to obtain a final moisture content of around $18 \%$. The dried squids were kept in plastic bags for 12 months. In 3 month-interval, they were sampled to analyse the acid value, peroxide value, carbonyl value, thiobarbituric acid (TBA) value.

Free radical scavenging activity (DPPH, mg Trolox/100 g) of Nepenthes extract was evaluated by the method described by Bakar et al. (2017). Acid value (mg $\mathrm{KOH} / \mathrm{g}$ ) was determined by titration by $0.1 \mathrm{~N} \mathrm{KOH}$ with phenolphthalein indicator to pink appearance. Peroxide value $(\mathrm{meq} / \mathrm{kg})$ was estimated by weighing $5 \mathrm{~g}$ of sample, adding $15 \mathrm{~mL}$ acetic acid and $10 \mathrm{~mL}$ chloroform, supplementing $1 \mathrm{~mL}$ KI solution. This mixture was kept in a dark place for 15 mins and a starch indicator was added. The final titration was defined by adding $0.01 \mathrm{~N} \mathrm{Na}_{2} \mathrm{~S}_{2} \mathrm{O}_{3}$ until colourless. Carbonyl value (meq $/ \mathrm{kg}$ ) was determined by high-performance liquid chromatography with ultraviolet (UV) detection (Vanessa and Zenilda, 2013). Thiobarbituric acid (TBA) value (mg malonaldehyde $/ \mathrm{kg}$ ) was measured by the 2 thiobarbituric acid spectrophotometric method (Anna et al., 2017).

\subsection{Statistical analysis}

The experiments were run in triplicates with different groups of samples. The data were presented as mean \pm standard deviation. Statistical analysis was performed by the Statgraphics Centurion version XVI.

\section{Results and discussion}

Free radical scavenging activity or DPPH (mg Trolox/100 g) of Nepenthes extract was shown at $75.83 \pm 0.03$ (mg Trolox/100 g) compared to butylated hydroxyanisole (BHA) solution $77.09 \pm 0.01 \quad(\mathrm{mg}$ Trolox/100 g). Nepenthes extract has excellent antioxidant capacity ideal for lipid oxidative prevention. Excellent antioxidant activity of pitcher extract might have originated from a synergistic impact of terpenes, terpenoids, essential oils and other available metabolites such as flavonoids (Adhikari et al., 2003; Grassmann, 2005; Ozturk, 2012). Tiewlasubon et al. (2014) reported that Nepenthes extract showed powerful antioxidant capacity with $23.33 \pm 0.441$ (mg Trolox/100 g). The leaf Nepenthes extract was demonstrated to be more effective than standard butylated hydroxytoluene (Ismail et al., 2015). In another research, the radical scavenging activity of the pitcher extract was noted at $0.148 \pm 0.04$ $\mathrm{mg} / \mathrm{mL}$ (Muhammad et al., 2018).

The acid value is commonly applied as an important indicator of fat rancidity. Under the incorporation of Nepenthes extract in the soaking solution, the dried squid had a low acid value similar to the sample treated by BHA during 12 months of storage. Meanwhile, the control sample had accumulated acid value every month (Table 1). At the end of 12 months of storage, the dried squid treated with Nepenthes extract still had a low acid value $(2.70 \pm 0.03 \mathrm{mg} \mathrm{KOH} / \mathrm{g})$. It is suggested that Nepenthes extract significantly retarded the rancidity in dried squid. These results were in accordance with other findings such as the herbal extract that was demonstrated to be effective in the control of lipid oxidation in dried eel (Song, 2019). Furthermore, green tea extract was also suitable to retard fat rancidity in mackerel (Nam et al., 2011). While the combination of spices (turmeric, chilli) greatly improved the quality of dried Taki (Rahman et al., 2017). Eryngium caucasicum extracts were also as effective to slow down the acid value of silver carp fillets (Raeisi et al., 2017).

Primary lipid oxidation was followed by the peroxide value (Servet and Hudayi, 2011). Peroxide values (meq $/ \mathrm{kg}$ ) of the dried squid treated by Nepenthes extract, butylated hydroxyanisole and control were all presented in Table 2. The supplementation of Nepenthes extract was able to maintain the peroxide value of the dried squid at a low amount $(2.91 \pm 0.01 \mathrm{meq} / \mathrm{kg})$ after 12 
Table 1. Acid value $(\mathrm{mg} \mathrm{KOH} / \mathrm{g})$ of the dried squid

\begin{tabular}{lccccc}
\hline Storage (month) & 0 & 3 & 6 & 9 & 12 \\
\hline Nepenthes extract $0.05 \%$ & $1.06 \pm 0.02^{\mathrm{ab}}$ & $1.45 \pm 0.00^{\mathrm{ab}}$ & $1.94 \pm 0.01^{\mathrm{b}}$ & $2.32 \pm 0.00^{\mathrm{b}}$ & $2.70 \pm 0.03^{\mathrm{b}}$ \\
Butylated hydroxyanisole 10 ppm & $0.98 \pm 0.01^{\mathrm{b}}$ & $1.29 \pm 0.03^{\mathrm{b}}$ & $1.85 \pm 0.02^{\mathrm{b}}$ & $2.21 \pm 0.01^{\mathrm{b}}$ & $2.59 \pm 0.02^{\mathrm{b}}$ \\
Control & $1.17 \pm 0.00^{\mathrm{a}}$ & $1.97 \pm 0.02^{\mathrm{a}}$ & $4.83 \pm 0.03^{\mathrm{a}}$ & $7.69 \pm 0.02^{\mathrm{a}}$ & $10.85 \pm 0.01^{\mathrm{a}}$ \\
\hline
\end{tabular}

Values are presented as mean $\pm \mathrm{SD}, \mathrm{n}=3$. Values with the same superscript within the same row are not significantly different $(\alpha$ $=5 \%$.

months of storage. Meanwhile, the peroxide value of the control sample increased dramatically from the $3^{\text {rd }}$ to the $12^{\text {th }}$ month. There was no significant difference in the peroxide value between those treated with Nepenthes extract and butylated hydroxyanisole. It is suggested that Nepenthes extract could safely be used and effectively minimize lipid oxidation. The effectiveness of rancidity retardation by Nepenthes extract was similar to other plant extracts such as the green tea extract that strongly retards the oxidative rancidity in eel oil (Song and Kim, 2018). The peroxide value of anchovy oil was kept at low content by green tea extract (Kang et al., 2007). Basil leaf essential oil was also effective to limit peroxide value in Sea bass slices (Arfat et al., 2015). Pomegranate peel extract was also appropriated for Nile tilapia fillets to slow down peroxide value (Alsaggaf et al., 2017). Eryngium caucasicum extract was found to be a beneficial substance to decrease peroxide value in Silver carp fillets (Raeisi et al., 2017).

Carbonyl is commonly originated from proteolysis and amino acid oxidation to release malondialdehyde. Carbonyl value $(\mathrm{meq} / \mathrm{kg})$ of the dried squid soaked in Nepenthes extract, butylated hydroxyanisole and control were all presented in Table 3. It was thoroughly realized that with the addition of Nepenthes extract, low traces of carbonyl values of the dried squid were obtained $(2.66 \pm 0.00 \mathrm{meq} / \mathrm{kg})$ after 12 months of storage. Meanwhile, the carbonyl value of the control sample increased steeply from the $3^{\text {rd }}$ to the $12^{\text {th }}$ month. There was no significant difference in carbonyl value between the squids that were treated by Nepenthes extract and butylated hydroxyanisole. It was recommended that Nepenthes extract could be utilized to replace butylated hydroxyanisole to control the carbonyl substance. This result was relevant to another study when eels treated with green tea extract had a low carbonyl value (Choi, 2006).

In the evaluation of oxidative rancidity, the thiobarbituric acid (TBA) value should be mentioned. It is an important quality indicator to measure fat oxidation for dried and semi-dried seafood (Bahar et al., 2006). The basic mechanism of this procedure is the interaction of 1 molecule of malonaldehyde and 2 molecules of TBA to release a purple appearance of the malonaldehyde-TBA complex. Table 4 shows the influence of Nepenthes extract demonstrated with butylated hydroxyanisole to control the TBA value. It was found that the Nepenthes extract effectively retarded TBA formation in the dried squid during 12 months of storage. These results were relevant to fennel extracts

Table 2. Peroxide value $(\mathrm{meq} / \mathrm{kg})$ of the dried squid

\begin{tabular}{lccccc}
\hline Storage (month) & 0 & 3 & 6 & 9 & 12 \\
\hline Nepenthes extract $0.05 \%$ & $1.34 \pm 0.03^{\mathrm{a}}$ & $1.75 \pm 0.02^{\mathrm{b}}$ & $2.03 \pm 0.00^{\mathrm{b}}$ & $2.48 \pm 0.02^{\mathrm{b}}$ & $2.91 \pm 0.01^{\mathrm{b}}$ \\
Butylated hydroxyanisole $10 \mathrm{ppm}$ & $1.28 \pm 0.02^{\mathrm{a}}$ & $1.69 \pm 0.01^{\mathrm{b}}$ & $1.98 \pm 0.03^{\mathrm{b}}$ & $2.37 \pm 0.00^{\mathrm{b}}$ & $2.80 \pm 0.00^{\mathrm{b}}$ \\
Control & $1.42 \pm 0.03^{\mathrm{a}}$ & $4.27 \pm 0.03^{\mathrm{a}}$ & $7.93 \pm 0.01^{\mathrm{a}}$ & $11.86 \pm 0.03^{\mathrm{a}}$ & $18.70 \pm 0.02^{\mathrm{a}}$ \\
\hline
\end{tabular}

Values are presented as mean $\pm \mathrm{SD}, \mathrm{n}=3$. Values with the same superscript within the same row are not significantly different $(\alpha$ $=5 \%$ ).

Table 3. Carbonyl value (meq/kg) of the dried squid

\begin{tabular}{lccccc}
\hline Storage (month) & 0 & 3 & 6 & 9 & 12 \\
\hline Nepenthes extract 0.05\% & $0.83 \pm 0.01^{\mathrm{a}}$ & $1.15 \pm 0.03^{\mathrm{b}}$ & $1.59 \pm 0.01^{\mathrm{b}}$ & $1.94 \pm 0.03^{\mathrm{b}}$ & $2.66 \pm 0.00^{\mathrm{b}}$ \\
Butylated hydroxyanisole 10 ppm & $0.79 \pm 0.00^{\mathrm{a}}$ & $1.04 \pm 0.02^{\mathrm{b}}$ & $1.48 \pm 0.02^{\mathrm{b}}$ & $1.87 \pm 0.03^{\mathrm{b}}$ & $2.59 \pm 0.01^{\mathrm{b}}$ \\
Control & $0.84 \pm 0.00^{\mathrm{a}}$ & $3.68 \pm 0.03^{\mathrm{a}}$ & $8.53 \pm 0.00^{\mathrm{a}}$ & $14.73 \pm 0.02^{\mathrm{a}}$ & $19.93 \pm 0.00^{\mathrm{a}}$ \\
\hline
\end{tabular}

Values are presented as mean $\pm \mathrm{SD}, \mathrm{n}=3$. Values with the same superscript within the same row are not significantly different $(\alpha$ $=5 \%)$.

Table 4. Thiobarbituric acid value (mg malonaldehyde $/ \mathrm{kg}$ ) of the dried squid

\begin{tabular}{lccccc}
\hline Storage (month) & 0 & 3 & 6 & 9 & 12 \\
\hline Nepenthes extract 0.05\% & $1.07 \pm 0.03^{\mathrm{a}}$ & $1.70 \pm 0.00^{\mathrm{b}}$ & $2.02 \pm 0.02^{\mathrm{b}}$ & $2.68 \pm 0.01^{\mathrm{b}}$ & $2.95 \pm 0.03^{\mathrm{b}}$ \\
Butylated hydroxyanisole 10 ppm & $1.02 \pm 0.01^{\mathrm{a}}$ & $1.63 \pm 0.00^{\mathrm{b}}$ & $1.97 \pm 0.01^{\mathrm{b}}$ & $2.59 \pm 0.00^{\mathrm{b}}$ & $2.93 \pm 0.02^{\mathrm{b}}$ \\
Control & $1.13 \pm 0.02^{\mathrm{a}}$ & $5.54 \pm 0.01^{\mathrm{a}}$ & $9.13 \pm 0.03^{\mathrm{a}}$ & $16.07 \pm 0.00^{\mathrm{a}}$ & $23.46 \pm 0.01^{\mathrm{a}}$ \\
\hline
\end{tabular}

Values are presented as mean $\pm \mathrm{SD}, \mathrm{n}=3$. Values with the same superscript within the same row are not significantly different $(\alpha$ $=5 \%$ ). 
that were ideal to increase the stability of silver carp fillets by slowing down TBA value (Mazandrani et al., 2016). Eryngium caucasicum extract was also effective to limit the TBA value of silver carp fillets (Raeisi et al., 2017).

\section{Conclusion}

Pitcher (Nepenthes) extract was rich in bioactive components, mainly polyphenols, which are valuable alternatives to replace synthetic antioxidants in seafood processing and preservation. Findings of this research concluded that Pitcher (Nepenthes) extract revealed excellent antioxidant potential to retard an accumulation of lipid oxidation in the dried squid. Its incorporation during soaking fresh squid would maintain the acid value, peroxide value, carbonyl value and TBA value at the low amount in the dried squid. It would be considered as an upcoming alternative to reduce the consumption of synthetic additives due to concerns of the possible toxic effects.

\section{Conflict of interest}

The author strongly confirms that this research was conducted with no conflict of interest.

\section{Acknowledgement}

We acknowledge the financial support for the publication provided by Binh Duong University, Thu Dau Mot city, Binh Duong province, Vietnam.

\section{References}

Adhikari, S., Joshi, R., Patro, B., Ghanty, T., Chintalwar, G., Sharma, A., Chattopadhyay, S. and Mukherjee, T. (2003). Antioxidant activity of bakuchiol: Experimental evidences and theoretical treatments on the possible involvement of the terpenoid chain. Chemical Research in Toxicology, 16(9), 1062-1069. https://doi.org/10.1021/tx034082r

Alirezalu, K., Pateiro, M., Yaghoubi, M., Alirezalu, A., Peighambardoust, S.H. and Lorenzo, J.M. (2020). Phytochemical constituents, advanced extraction technologies and techno-functional properties of selected Mediterranean plants for use in meat products. A comprehensive review. Trends Food Science Technology, 100(2), 292-306. https:// doi.org/10.1016/j.tifs.2020.04.010

Alsaggaf, M.S., Moussa, S.H. and Tayel, A.A. (2017). Application of fungal chitosan incorporated with pomegranate peel extract as edible coating for microbiological, chemical and sensorial quality enhancement of Nile tilapia fillets. International Journal of Biological Macromolecules, 99(6), 499-
505. https://doi.org/10.1016/j.ijbiomac.2017.03.017

Anna, R., Monika, S., Jozef, N., Slavomir, M., Boris, S., Milan, C. and Tatiana, K. (2017). Lipid peroxidation process in meat and meat products: a comparison study of malondialdehyde determination between modified 2-thiobarbituric acid spectrophotometric method and reverse-phase high-performance liquid chromatography. Molecules, 22(11), 1988. https:// doi.org/10.3390/molecules22111988

Arfat, Y.A., Benjakul, S., Vongkamjan, K., Sumpavapol, P. and Yarnpakdee, S. (2015). Shelf-life extension of refrigerated sea bass slices wrapped with fish protein isolate/fish skin gelatin- $\mathrm{ZnO}$ nanocomposite film incorporated with basil leaf essential oil. Journal of Food Science and Technology, 52(1), 6182-6193. https://doi.org/10.1007/s13197-014-1706-y

Ashrafi, A., Jokar, M. and Mohammadi-Nafchi, A. (2018). Preparation and characterization of biocomposite film based on chitosan and kombucha tea as active food packaging. International Journal of Biological Macromolecules, 108(1), 444-454. https://doi.org/10.1016/j.ijbiomac.2017.12.028

Aung, H., Chia, L., Goh, N., Chia, T., Ahmed, A., Pare, P. and Mabry, T. (2002). Phenolic constituents from the leaves of the carnivorous plant Nepenthes gracilis. Fitoterapia, 73(5), 445-447. https:// doi.org/10.1016/s0367-326x(02)00113-2

Bahar, T., Koray, K. and Deniz, A. (2006). Comparison of two thiobarbituric acid (TBA) method for monitoring lipid oxidation in fish. European Journal of Fisheries and Aquatic Sciences, 23(3), 331-334.

Bakar, M.F.A., Sanusi, S.B., Bakar, F.I.A., Cong, O.J. and Mian, Z. (2017). Physicochemical and antioxidant potential of raw unprocessed honey from Malaysian stingless bees. Pakistan Journal of Nutrition, 16(11), 888-894. https://doi.org/10.3923/ pjn.2017.888.894

Barros, L., Ferreira, M.J., Queiros, B., Ferreira, I.C. and Baptista, P. (2007). Total phenols, ascorbic acid, $\beta$ carotene and lycopene in Portuguese wild edible mushrooms and their antioxidant activities. Food Chemistry, 103(2), 413-419. https://doi.org/10.1016/ j.foodchem.2006.07.038

Beck, C. (2014). Effects of high pressure processing on lipid oxidation: A review. Innovative Food Science and Emerging Technology, 22(2), 1-10. https:// doi.org/10.1016/j.ifset.2013.10.012

Cando, D., Morcuende, D., Utrera, M. and Estevez, M. (2014). Phenolic-rich extracts from Willowherb (Epilobium hirsutum L.) inhibit lipid oxidation but accelerate protein carbonylation and discoloration of beef patties. European Food Research Technology, 
238(1), 741-751. https://doi.org/10.1007/s00217-014 $-2152-9$

Carocho, M. and Ferreira, I.C. (2013). A review on antioxidants, prooxidants and related controversy: Natural and synthetic compounds, screening and analysis methodologies and future perspectives. Food and Chemical Toxicology, 51(1), 15-25. https://doi.org/10.1016/j.fct.2012.09.021

Choi, B.D., Kang, S.J., Ha, Y.L., Kim, S.Y. and Lee, J.J. (2006). Oxidative stability of lipids from eel (Anguilla japonica) fed conjugated linoleic acid. Journal of the Korean Society of Food Science and Nutrition, 35(1), 61-67. https://doi.org/10.3746/ jkfn.2006.35.1.061

Dominguez, R., Munekata, P.E.S., Pateiro, M., Maggiolino, A., Bohrer, B. and Lorenzo, J.M. (2020). Red beetroot. A potential source of natural additives for the meat industry. Applied Sciences, 10 (23), 8340. https://doi.org/10.3390/app10238340

Frankel, E.N. (1984). Chemistry of free radical and singlet oxidation of lipids. Progress in Lipid Research, 23(4), 197-221. https:// doi.org/10.1016/0163-7827(84)90011-0

Fraser, O. and Sumar, S. (1998). Compositional changes and spoilage in fish-an introduction. Nutrition and Food Science, 98(5), 275-279. https:// doi.org/10.1108/00346659810224208

Ghayempour, S., Montazer, M. and Mahmoudi, R.M. (2015). Tragacanth gum as a natural polymeric wall for producing antimicrobial nanocapsules loaded with plant extract. International Journal of Biological Macromolecules, 81(4), 514-520. https:// doi.org/10.1016/j.ijbiomac.2015.08.041

Grassmann, J. (2005). Terpenoids as plant antioxidants. Vitamins and Hormones, 72(1), 505-535. https:// doi.org/10.1016/S0083-6729(05)72015-X

Hsieh, R.J. and Kinsella, J.E. (1989). Oxidation of polyunsaturated fatty acids: Mechanisms, products, and inhibition with emphasis on fish. Advance Food Nutrition Research, 33(1), 233-341. https:// doi.org/10.1016/s1043-4526(08)60129-1

Ismail, N.A., Kamariah, A.S., Lim, L.B. and Ahmad, N. (2015). Phytochemical and pharmacological evaluation of methanolic extracts of the leaves of Nepenthes bicalcarata Hook. F. International Journal of Pharmacognosy and Phytochemical Research, 7(6), 1127-1138.

Kang, S.T., Yoo, U.H., Nam, K.H., Kang, J.Y. and Oh, K.S. (2007). Antioxidative effects of green tea extract on the oxidation of anchovy oil. Journal of Agriculture and Life Science, 41(3), 47-53.

Kharchoufi, S., Licciardello, F., Siracusa, L., Muratore,
G., Hamdi, M. and Restuccia, C. (2018). Antimicrobial and antioxidant features of 'Gabsi' pomegranate peel extracts. Industrial Crops and Products, 111(1), 345-352. https://doi.org/10.1016/ j.indcrop.2017.10.037

Likhitwitayawuid, K., Kaewamatawong, R., Ruangrungsi, N. and Krungkrai, J. (1998). Antimalarial naphthoquinones from Nepenthes thorelii. Planta Medicine, 64(3), 237-241. https:// doi.org/10.1055/s-2006-957417

Lorenzo, J.M., Pateiro, M., Dominguez, R., Barba, F.J., Putnik, P., Kovacevic, D.B., Shpigelman, A., Granato, D. and Franco, D. (2018). Berries extracts as natural antioxidants in meat products: A review. Food Research International, 106(2), 1095-1104. https://doi.org/10.1016/j.foodres.2017.12.005

Losada, V., Barros-Velázquez, J. and Aubourg, S.P. (2007). Rancidity development in frozen pelagic fish: Influence of slurry ice as preliminary chilling treatment. LWT-Food Science and Technology, 40 (6), 991-999. https://doi.org/10.1016/ j.lwt.2006.05.011

Lugasi, A., Losada, V., Hovari, J., Lebovics, V., Jakoczi, I. and Aubourg, S. (2007). Effect of pre-soaking whole pelagic fish in a plant extract on sensory and biochemical changes during subsequent frozen storage. LWT-Food Science and Technology, 40(5), 930-936. https://doi.org/10.1016/j.lwt.2005.09.021

Mazandrani, H.A., Javadian, S. and Bahram, S. (2016). The effect of encapsulated fennel extracts on the quality of silver carp fillets during refrigerated storage. Food Science Nutrition, 4(2), 298-304. https://doi.org/10.1002/fsn3.290

Muhammad, A.F.R., Kamalrul, A.A. and Hoe-Han, G. (2018). Antioxidant activity of pitcher extracts from three Nepenthes species. Sains Malaysiana, 47(12), 3069-3075. https://doi.org/10.17576/jsm-2018-4712 $-17$

Munekata, P.E.S., Gullon, B., Pateiro, M., Tomasevic, I., Dominguez, R. and Lorenzo, J.M. (2020). Natural antioxidants from seeds and their application in meat products. Antioxidants, 9(9), $815 . \quad \mathrm{https}: / /$ doi.org/10.3390/antiox9090815

Nam, K.H., Jang, M.S., Lee, D.S., Yoon, H.D. and Park, H.Y. (2011). Effect of green tea and lotus leaf boiled water extracts treatment on quality characteristics in salted mackerel during storage. Korean Journal of Food Preservation, 18(5), 643-650. https:// doi.org/10.11002/kjfp.2011.18.5.643

Ozturk, M. (2012). Anticholinesterase and antioxidant activities of savoury (Satureja thymbra L.) with identified major terpenes of the essential oil. Food 
Chemistry, 134(1), 48-54. https://doi.org/10.1016/ j.foodchem.2012.02.054

Patel, V.R., Patel, P.R. and Kajal, S.S. (2010). Antioxidant activity of some selected medicinal plants in western region of India. Advances in Biological Research, 4(1), 23-26.

Raeisi, S., Ojagh, S.M., Sharifi-Rad, M., Sharifi-Rad, J. and Quek, S.Y. (2017). Evaluation of Allium paradoxum (M.B.) G. Don. and Eryngium caucasicum trauve. Extracts on the shelf-life and quality of silver carp (Hypophthalmichthys molitrix) fillets during refrigerated storage. Journal of Food Safety, 37(3), 12321. https://doi.org/10.1111/ jfs. 12321

Rahman, M.S., Rasul, M.G., Hossain, M.M., Uddin, W., Majumdar, B.C., Sarkar, M.S.I. and Bapary, M.A.J. (2017). Impact of spice treatments on the quality and shelf life of sun dried taki (Channa punctatus). Journal of Chemical, Biological and Physical Sciences, 7(72), 409-420.

Reddy, A. and Grace, J.R. (2016). In vitro evaluation of antioxidant activity of methanolic extracts of selected mangrove plants. Medicinal and Aromatic Plants, 5(3), 250-255. https://doi.org/10.4172/21670412.1000250

Sanusi, S.B., Bakar, M.F.A., Mohamed, M., Sabran, S.F. and Mainasara, M.M. (2017). Ethnobotanical, phytochemical, and pharmacological properties of Nepenthes species: A review. Asian Journal of Pharmaceutical and Clinical Research, 10(11), 1619. https://doi.org/10.22159/ ajpcr.2017.v10i11.20050

Schwallier, R., de Boer, H.J., Visser, N., van Vugt, R.R. and Gravendeel, B. (2015). Traps as treats: A traditional sticky rice snack persisting in rapidly changing Asian kitchens. Journal of Ethnobiology and Ethnomedicine, 11, 24. https://doi.org/10.1186/ s13002-015-0010-x

Servet, A. and Hudayi, E. (2011). Chemical composition of European squid and effects of different frozen storage temperatures on oxidative stability and fatty acid composition. Journal of Food Science and Technology, 48(1), 83-89. https://doi.org/10.1007/ s13197-010-0139-5

Shil, D., Mohanty, J.P., Das, T., Bhuyan, N.R. and Uriah, T. and Mohamed-Saleem, T.S. (2010). Protective role of pitcher of Nepenthes khasiana Hook against dexamethazone induced hyperlipidemia and insulin resistance in rat. International Journal Research Pharmaceutical Science, 1(2), 195-198.

Shuaibu, B.S., Mohd, F.A.B., Maryati, M., Siti, F.S. and
Muhammad, M.M. (2017). Ethnobotanical, phytochemical, and pharmacological properties of Nepenthes species: A review. Asian Journal of Pharmaceutical and Clinical Research, 10(11), 1619. ajpcr.2017.v10i11.20050

Smaou, S., Hlima, H.B., Mtibaa, A.C., Fourati, M., Sellem, I., Elhadef, K., Ennouri, K. and Mellouli, L. (2019). Pomegranate peel as phenolic compounds source: Advanced analytical strategies and practical use in meat products. Meat Science, 158(4), 107914.

Song, H.S. (2019). Antioxidant effects of ethanol extracts from plants on semi-dried eels. Korean Journal of Food Preservation, 26(1), 109-114. https://doi.org/10.11002/kjfp.2019.26.1.109

Song, H.S. and Kim, Y.M. (2018). Antioxidant effects of ethanol extracts from plants on peroxide content in semi-dried eels. The Korean Journal of Food and Nutrition, 31(5), 647-652. https://doi.org/10.11002/ kjfp.2019.26.1.109

Sood, V., Tian, W., Narvaez-Bravo, C., Arntfield, S.D. and Gonzalez, A.R. (2020). Plant extracts effectiveness to extend bison meat shelf life. Journal of Food Science, 85(4), 936-946. https:// doi.org/10.1111/1750-3841.15062

Stina, C.M.B., Anders, E., Uko, B., Tonu, P., Martin, J., Jarkko, H., Sari, M., Risto, K., Pirjo, H.M., Vitalijs, R., Dalija, S., Asa, H., Kimmo, R. and Eva, T. (2020). Lipid oxidation inhibition capacity of plant extracts and powders in a processed meat model system. Meat Science, 162(2), 108033. https:// doi.org/10.1016/j.meatsci.2019.108033

Thao, N.P., Luyen, B.T.T., Koo, J.E., Kim, S., Koh, Y.S., Thanh, N.V., Cuong, N.X., Kiem, P.V., Minh, C.V. and Kim, Y.H. (2016). In vitro antiinflammatory components isolated from the carnivorous plant Nepenthes mirabilis (Lour.) Rafarin. Pharmaceutical Biology, 54(4), 588-594. https://doi.org/10.3109/13880209.2015.1067234

Tiewlasubon, U., Mrityunjaya, B.P. and Sivaiah, K. (2015). In vitro antioxidant and hepatoprotective potential of Nepenthes Khasiana Hook. F against ethanol-induced. Journal of Pharmaceutical Research, 14(4), 81-89. https://doi.org/10.18579/ jpcrkc/2015/14/4/89467

Van Thanh, N., Thao, N.P., Huong, P.T., Lee, S.H., Jang, H.D. and Cuong, N.X. (2015). Naphthoquinone and flavonoid constituents from the carnivorous plant Nepenthes mirabilis and their antiosteoporotic and antioxidant activities. Phytochemical Letters, 11(1), 254-259. https:// doi.org/10.1016/j.phytol.2015.01.009 
Vanessa, M.O. and Zenilda, L.C. (2013). Analytical methods to assess carbonyl compounds in foods and beverages. Journal of the Brazilian Chemical Society, 24(11), 1711-1718. https:// doi.org/10.5935/0103-5053.20130236

Wan-Nor-Adibah-Wan, Z., Loke, K.K., Zulkapli, M.M., Salleh, I.M., Goh, H.H. and Noor, N.M. (2016). RNA-seq analysis of Nepenthes ampullaria. International Journal of Plant Science, 164(1), 635639. https://doi.org/10.3389/fpls.2015.01229

Wang, L., Zhou, Q., Zheng, Y. and Xu, S. (2009). Composite structure and properties of the pitcher surface of the carnivorous plant Nepenthes and its influence on the insect attachment system. Progress in Natural Science, 19(12), 1657-1664. https:// doi.org/10.1016/j.pnsc.2009.09.005 